\title{
Impacts of Service-Learning on the Professional Social Responsibility Attitudes of Engineering Students
}

\author{
Angela R. Bielefeldt \\ Professor, Department of Civil, Environmental \& \\ Architectural Engineering \\ University of Colorado Boulder \\ Boulder, CO 80309 \\ Angela.Bielefeldt@colorado.edu
}

\author{
Nathan Canney \\ Instructor, Department of Civil and Environmental \\ Engineering \\ Seattle University \\ Seattle, WA 98122 \\ canneyn@seattleu.edu
}

\begin{abstract}
This research explored correlations between the social responsibility attitudes of engineering students and their participation in service-learning and/or extracurricular engineering service activities, such as Engineers Without Borders (EWB). Social responsibility attitudes were measured using a survey with fifty Likert items. The survey also collected information about students' participation frequency in service-learning courses, EWB, and service trips. Survey responses were received from students at five institutions who were primarily in their first or senior year and majoring in civil, environmental, or mechanical engineering. Findings showed that incoming first-year students with higher frequency of service-learning participation during high school had higher average social responsibility. College service-learning courses had a beneficial impact on social responsibility attitudes. In open-ended responses, a number of students directly cited service-learning courses as impacting their views of social responsibility. Students who participated in EWB had more positive social responsibility attitudes than students who did not participate in EWB. This is due, primarily, to students with high social responsibility opting into activities like EWB. Future research is needed to determine the specific aspects of the service-learning experiences that foster positive attitudes toward social responsibility in engineering students, such as types of structured reflection and reciprocal partnerships with the community.
\end{abstract}

Index Terms - Engineers Without Borders, service-learning, social responsibility

\section{BACKGROUND}

Engineers are increasingly being called on to fully embrace their responsibility as professionals to serve the public and consider the societal implications of their work. ${ }^{\text {i-vi }}$ These attributes may be termed "professional social responsibility". The spectrum of activities that embody professional social responsibility span from encouraging a diverse range of stakeholders to be engaged in the engineering process to social justice issues. ${ }^{\text {vii-xi }}$ The social responsibility attitudes of individuals in engineering have been hypothesized to be comprised of three realms in the Professional Social Responsibility Development Model (PSRDM). ${ }^{\text {xii }}$ First, the personal social awareness realm encompasses one's disposition toward altruistic behavior, modeled after Schwartz. ${ }^{\text {xiii,xiv }}$ This includes an awareness of needs, belief in one's ability to act to help address these needs, and a feeling of moral obligation to help others. The second realm, professional development, addresses the importance of both technical and non-technical skills in engineering, that engineering skills can be applied to help solve social problems, and that it is important for 
engineers to hold a wide range of stakeholders in the engineering decision process. ${ }^{\mathrm{xv}}$ Finally, one's personal and professional attitudes combine into a sense of professional connectedness. In this realm individuals feel a moral obligation to help others using their professional skills, but also consider the costs and benefits of engaging in action. Similar to the Service Learning Model, ${ }^{\mathrm{xvi}}$ it is hypothesized that actually engaging in acts of service will deepen this commitment to serve society through engineering, i.e., one's professional connectedness. The model proposes that increasingly positive attitudes develop on a continuum through the realms, most readily in the early stages first and then increasingly in the later stages.

Learning through service (LTS) may be an effective means to help foster the development of social responsibility in engineering students. LTS has been defined as an umbrella term for activities that partner students and communities to serve community needs and meet learning goals. ${ }^{\text {xii }}$ LTS experiences are commonly included in many K-12 schools. ${ }^{\text {xviii }}$ In a 2012 national study of incoming first-year college students, 57.2\% of the 192,912 respondents reported they had frequently or occasionally "performed community service as part of a class" over the past year (their senior year of high school); this was down slightly from $59.0 \%$ of students in 2009. ${ }^{\text {xix,xx }}$ It has been shown that some colleges give weight and value to community service experiences in the college admissions process. ${ }^{\mathrm{xx}}$ However, it is unclear the extent to which this is valued in the admissions process to engineering schools. In the same thread, $72.0 \%$ of 2012 firstyear students nationally indicated that "helping others who are in difficulty" was an objective considered to be essential or very important; this was an increase from $69.1 \%$ in 2009 . ${ }^{\mathrm{x} x \mathrm{xx}}$ Again, it is unclear if engineering students match this national trend of being increasingly concerned with helping others. It should be noted that the specific characteristics of these service experiences, including how they were tied to learning objectives, was not reported in those studies.

Service-learning (SL) is being increasingly infused into engineering education. ${ }^{\text {xxii-xxv }}$ Servicelearning has been defined as "a credit-bearing educational experience in which students participate in an organized service activity that meets identified community needs and reflect on the service activity in such a way as to gain further understanding of the course content, a broader appreciation of the discipline, and an enhanced sense of civic responsibility."xxiv Lima and Oakes ${ }^{\mathrm{xxv}}$ have identified five distinct components of service-learning: service, academic content, partnerships and reciprocity, mutual learning, and reflection. Unfortunately, sometimes the term service-learning has been applied to situations that do not meet all of the criteria of this rigorous definition. ${ }^{\text {xxvi-xxviii }}$ Service-learning in social science courses often involves placements of students with community organizations, such as a senior center, followed by reflection that enables the student to understand the experience in the context of the specific learning goals for the course. ${ }^{\text {xxi }}$ In contrast, service-learning in engineering generally takes the form of projects that teams of students execute in partnership with a community using a consulting-type model, such as a bike trail design, interactive displays for a children's museum, or assistive technology devices for individuals. ${ }^{\text {xv-xxvii,xxix }}$ The most common engineering courses where service-learning is employed appears to be first-year engineering project courses and senior capstone design. Service-learning courses might also be electives, such as Purdue's EPICS program. ${ }^{\text {xxix }}$ Servicelearning has been shown to encourage an increased interest in civic engagement. ${ }^{\text {xxix-xxxii }}$ It is unclear if or how a sense of civic engagement relates to students' view of professional social responsibility, and if service-learning can foster professional social responsibility attitudes in engineering students. 
Some extracurricular engineering service activities also fall under the umbrella of LTS. Engineers Without Borders (EWB) gained rapid popularity in the U.S., growing to over 12,000 members since its inception in 2001. ${ }^{\text {xxiii }}$ One of the goals of EWB-USA is to provide transformational educational experiences, but the actual outcomes to volunteers from EWB-USA involvement are still being determined. ${ }^{\text {xxiv }}$ A recent study among EWB-USA members found that societal awareness and awareness of engineering impacts were among the top five themes in open-ended responses to the question "what do you think an engineer needs to know?" (18.6\% and $13.2 \%$, respectively); but far fewer listed these among the biggest gains that resulted from their experience with EWB-USA (5.7\% and 6.5\%, respectively). ${ }^{\text {xxiii }}$ It is therefore unclear if and how EWB-USA involvement by students may impact their views of professional social responsibility.

The lack of clarity regarding the effects of engaging in LTS activities, specifically with respect to engineering students' views of social responsibility, led to the following research questions.

1) Do first-year students who participated in service-learning courses in high school have a heightened sense of personal social responsibility compared to students who had not participated in service-learning courses?

2) Do students who have taken service-learning courses in college have a heighted sense of personal and/or professional social responsibility compared to students who have not participated in college-level service-learning courses? If so, what courses and course attributes are important?

3) Does extracurricular engineering service participation in an organization such as EWBUSA impact students' sense of professional social responsibility?

\section{METHODS}

First year and senior undergraduate students at five institutions (Table I) were invited to take an online survey to measure their social responsibility and to identify their prior participation in service-learning, service trips, and extracurricular engineering service organizations such as EWB. The survey targeted primarily civil engineering (CE), environmental engineering (EnvE), and mechanical engineering (ME) students. Students at two institutions do not directly matriculate into engineering majors, so students had a wider array of potential and eventual engineering majors. Sophomore students were invited to participate at one institution where students have not even selected engineering yet in the first year, which resulted in a very low response rate among first year students. The invitation to participate in the online survey was emailed to students from college-provided email lists of students at the appropriate rank and major in September 2012 (Survey \#1). The response rate to the initial survey was about 20-25\% at each institution (see further details in Canney ${ }^{\mathrm{xxv}}$ ). Students who responded to the initial survey were emailed an invitation to take the survey again in April 2013 (Survey \#2) and March 2014 (Survey \#3). Students received a \$5 gift card for completing the initial survey and $\$ 10$ for completing the follow-up surveys (with the exception of one institution that did not allow incentives). The student email address or name was used to link the survey responses over time. All research was conducted in accordance with methods approved by the Institutional Review Board (IRB) for Human Subjects Research.

Students' sense of professional social responsibility was measured using the Engineering Professional Social Responsibility Assessment (EPRA) survey (available online). ${ }^{\text {xxxvi }}$ The survey 
instrument was based on the Professional Social Responsibility Development Model (PSRDM). ${ }^{\text {xii }}$ The survey was developed from 2011 to 2013 and showed strong evidence of reliability and validity. ${ }^{\mathrm{xxxvi}}$ The survey measures social responsibility (SR) in the three realms of the PSRDM described earlier (personal social awareness, professional development, and professional connectedness). The questions used to evaluate SR were 50 items that students responded to using a 7 -point Likert scale $(1=$ strongly disagree, $7=$ strongly agree $)$. Some items were negatively worded, and responses were reversed prior to averaging into the score for each SR dimension. The overall average SR score was the average across the 50 Likert items, and could range from 1 to 7 . Scores for realms were computed in the same way, by averaging the student responses across the items that mapped to that realm. For further details on the survey instrument and its validity/reliability see Canney and Bielefeldt. ${ }^{\text {xxvi }}$

\section{TABLE I}

NUMBER OF UNDERGRADUATE STUDENTS FROM DIFFERENT INSTITUTIONS WHO PARTICIPATED IN THE STUDY

\begin{tabular}{|c|c|c|c|c|}
\hline $\begin{array}{l}\text { Institution } \\
\text { Pseudonym }\end{array}$ & Notable Community Service in Engineering & $\begin{array}{l}\text { \# respondents, } \\
\text { pre survey } \\
\text { Sept. } 2012 \\
\text { (Survey \#1) }\end{array}$ & $\begin{array}{l}\text { \# respondents, } \\
\text { post survey } \\
\text { April } 2013 \\
\text { (Survey \#2) }\end{array}$ & $\begin{array}{l}\text { \# respondents, } \\
\text { delayed post survey } \\
\text { March 2014 } \\
\text { (Survey \#3) }\end{array}$ \\
\hline $\begin{array}{l}\text { Technical } \\
\text { Public }\end{array}$ & $\begin{array}{l}\text { International service-learning senior design } \\
\text { elective, active EWB student chapter, and } \\
\text { international development focus certificate }\end{array}$ & 261 & 187 & 138 \\
\hline Large Public & $\begin{array}{l}\text { Some service-learning sections of first-year } \\
\text { projects, some service-learning projects in } \\
\text { senior design and junior ME course, active } \\
\text { EWB student chapter and new Bridges to } \\
\text { Prosperity chapter }\end{array}$ & 187 & 123 & 52 \\
\hline Military & $\begin{array}{l}\text { National service mission, new EWB student } \\
\text { chapter }\end{array}$ & 108 & 39 & 11 \\
\hline Medium Public & $\begin{array}{l}\text { Service-learning infused into CE/EnvE } \\
\text { curriculum via NSF DLR grant, particularly in } \\
\text { first year introductory course and senior } \\
\text { design; EWB student chapter }\end{array}$ & 82 & 56 & 26 \\
\hline Private & $\begin{array}{l}\text { Service mission of institution, service brought } \\
\text { into courses intermittently by professors, } \\
\text { EWB student chapter }\end{array}$ & 79 & 45 & 36 \\
\hline TOTAL & & 717 & 450 & 263 \\
\hline
\end{tabular}

Another component of the survey asked students to rate the frequency in which they had engaged in a variety of community service activities. The activities listed included, among others: in-class service-learning project (i.e. service orientated capstone project), EWB or Engineers for Sustainable World (ESW) project, and three types of service trips: short term onsite service projects (i.e. spring break service trip, EWB/ESW in-country work), disaster relief volunteering, and international humanitarian volunteering. Service-learning (SL) was not defined for students nor were students asked to justify experiences that they deemed to be SL, so it was left to them as to how they decided whether or not they had experienced SL. It is presumed that some respondents may have loosely interpreted any course-based community service as SL. The options for participation frequency in the service-learning class and EWB-type activity were: none (0), once (1), twice (2), more than twice but not routinely (3), monthly (4), and weekly (5). 
The service trip frequency options were: none, once, twice, more than twice. During data analysis, sometimes these frequencies were recoded into fewer frequency categories. Students were also asked to indicate reasons they did or did not participate in community service activities, from among a range of options. The survey also included a few open-ended questions, which varied based on the goals of the survey administration. The final section of the survey asked a range of demographic questions including academic rank and major.

Statistical analysis of the data was conducted to detect differences in the social responsibility attitudes of the students based on their self-reported participation in service-learning, community service trips, or extracurricular service organizations such as EWB. The overall SR and realm scores were treated as continuous variables, since the averaging process resulted in a continuum of scores. ${ }^{\text {xxvii }}$ Analysis utilized t-tests (two-tailed, heteroscedastic) in Excel to compare two categories of data and paired t-tests to compare individuals over time; these tests have been shown to generally have a low Type II error rate (failing to identify a difference when one exists) with Likert items. ${ }^{\text {xxviii }}$ The advantage of the t-tests was the ability to use all of the items that comprised the construct for the comparison (such as the 50 individual Likert questions that comprised the overall average SR), rather than simply the single composite score. Nonparametric statistical tests were also conducted because the SR and realm scores were not normally distributed. ${ }^{\text {xxxvii,xxxviii }}$ Mann-Whitney $U$ tests are the non-parametric equivalent to t-tests and Kruskal-Wallis tests are the non-parametric equivalent of ANOVA. These non-parametric tests were conducted using the software package IBM SPSS version 22.

There were small differences in the non-SR questions on each distribution of the survey. The initial pre survey asked first-year students to indicate the typical frequency that they had engaged in community service before coming to college. The non-first-year students were asked to indicate the typical frequency that they had engaged in community service activities since beginning college. The initial survey also included an open-ended question that asked students to briefly describe any events that influenced their views of community service and social responsibility. Survey \#2 asked students to report the frequency that they had engaged in community service activities since the beginning of the school year. This survey also asked students if there were any classes in the last academic year that they found influential to their view of SR, why and in what ways. Survey \#3 asked students the average frequency that they had engaged in community activities in college, as well as if courses had impacted their views of social responsibility. These open-ended responses provide information on college courses or extracurricular activities that students found personally important. Deductive, manifest content analysis was conducted to extract information from the open-ended responses. ${ }^{\text {xxix }}$ Responses were scored based on the presence or absence of comments related to the course-based and extracurricular community service activities of interest in this research.

Service-learning and community service opportunities in engineering at each participating institution were explored using online information and interviews with engineering faculty. The goal of this exploration was to determine if there were any required courses in the civil, environmental, or mechanical engineering curricula that included service-learning. Significant findings from this exploration are summarized in Table I and will be used to contextualize the data in the study. 


\section{RESULTS AND DISCUSSION}

\section{Incoming First-Year Students}

Of the 259 first-year students who responded to Survey \#1, 35\% reported working on an in-class service-learning project in high school. There was a small increase in the average overall social responsibility (SR) scores with increased frequency of high school service-learning (SL) courses, as shown in Figure I and Table II. The impacts of service-learning on how students saw their personal ability and obligation to help others (personal social awareness) were not realized until the participation frequency was more than twice, while any level of service-learning participation showed a significant impact on how students viewed their professional obligation to help others (professional connectedness). No statistically significant effects of differential service-learning participation were found in how students viewed the role of social context in the engineering design process (professional development).

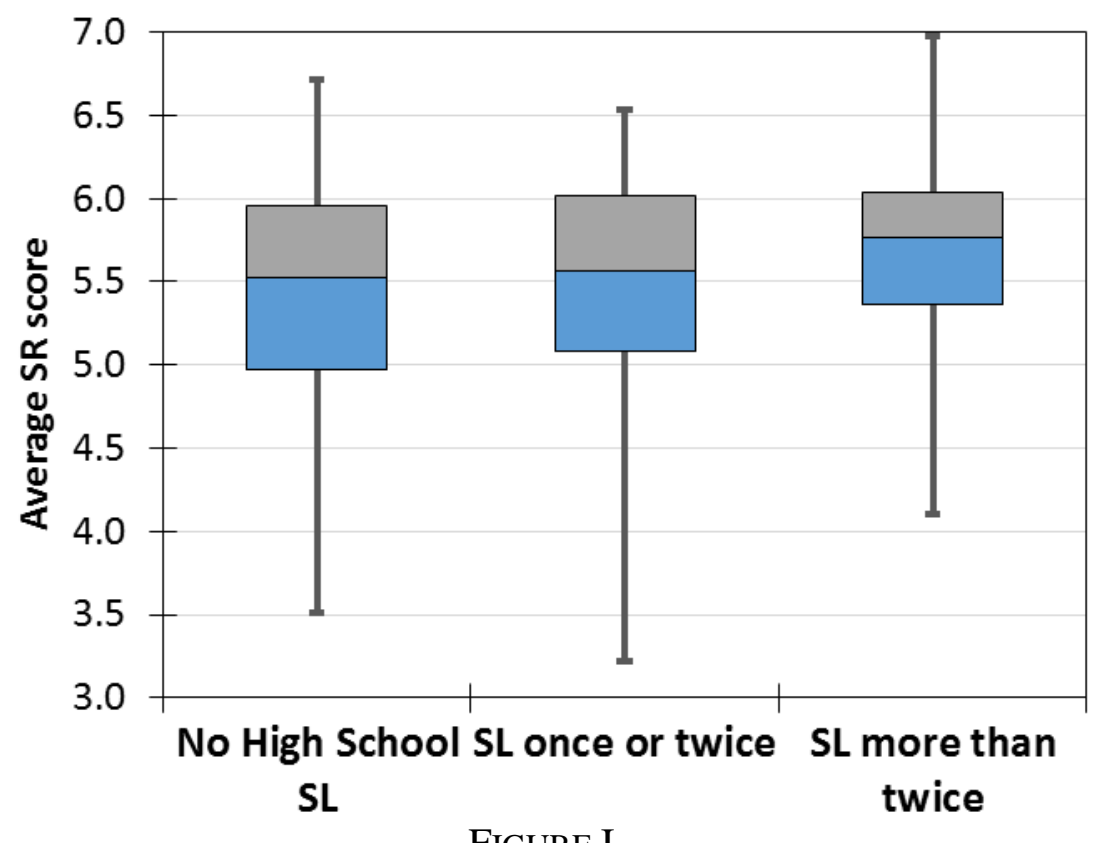

FIGURE I.

BOX PLOT OF SR SCORES FOR INCOMING FIRST-YEAR STUDENTS WITH DIFFERENT SERVICE-LEARNING (SL) EXPERIENCE IN HIGH SCHOOL; MINIMUM, FIRST QUARTILE, MEDIAN, THIRD QUARTILE, AND MAXIMUM SCORES SHOWN.

The positive benefits of service-learning on students' social responsibility attitudes were supported by open-ended responses to the question about events that influenced students' views of community service or social responsibility. Example quotes from students include:

"One event that influenced my views of community service and social responsibility was when I participated in meals on wheels. I was just going in for a grade for school, but I ended up seeing how much good I was doing for the community by helping out there and now I go back every year when I am on school vacation."

"Every time I go and volunteer, it always makes me feel good about doing it. One example is my high school capstone service project where we ran a book drive for kids who can't afford books." 
"The first time I really began any community service was through National Honors Society because I "had to" for the credits. When I actually began volunteering regularly, I found that I really did get something out of it."

It is unclear if these course-based community service experiences would fulfill the rigorous definition of service-learning. Methods used do not provide specific learning objectives being fulfilled through the service activity and whether or not the students were required to reflect on their service experience in this context. We can conclude that the student sample is pointing to service experience which were required as part of a course as being positively influential in their views of social responsibility.

The students who participated in service trips (short term on-site service project such as a spring break service trip, disaster relief volunteering, or international humanitarian volunteering) had a significantly higher average social responsibility score, personal social awareness, and professional connectedness than the students who had not participated in a service trip (Table II). This indicates that community service in high school outside of service-learning courses impacted students' views of SR. In open-ended responses describing events that influenced their views of SR, $12 \%$ of the students who reported participating in service-learning in high school described service trips to help out after natural disasters or mission trips with church groups, compared to only 5\% who described course-based service. Students also mentioned an array of other volunteer activities such as tutoring, working at homeless shelters or food banks, etc., but it wasn't clear if these were voluntary activities or required service activities as part of a class.

TABLE II.

HIGH SCHOOL SERVICE-LEARNING ACTIVITIES AND SR OF INCOMING FIRST-YEAR ENGINEERING STUDENTS

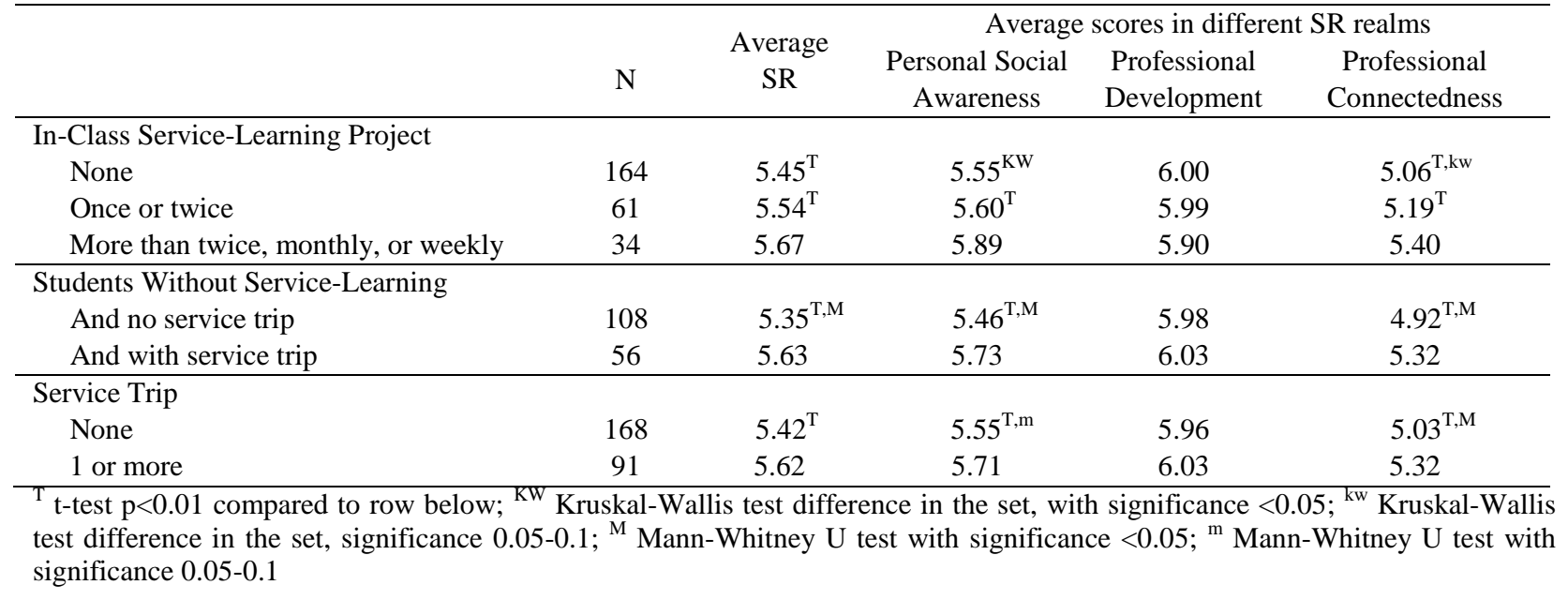

Student quotes made it clear that community service experiences were not always perceived as voluntary by the students and it was unclear if the students found them beneficial. Some example quotes from students that illustrate this perspective are shown below.

"For graduation from high school, we needed a certain number of volunteering hours, and I did not like volunteering ...."

"Several hours of community service were required to graduate from my high school, so I have come to look upon it as more of a hindrance."

"I did community service to be confirmed and to get into college that is it." 
Four students also shared how engineering related to their community service goals for the future. Example statements included:

"Doing community service, I never felt as though what I was physically doing actually helped anyone. Whether it was serving and sorting food or leading around horses, there was nothing about the work that needed me. I was always simply a paper pusher or a mindless robot. With engineering, I feel as though what I am doing will not only make a difference in someone's life, but it will be something that only I could have done."

"I went on Church Youth Group mission trips two years in high school. The volunteer work that I did there did not require extensive skill as it was aimed at high school students. In the future, I hope to participate in programs that allow me to use my engineering expertise to help others through projects like constructing clean water wells."

"I went on a kayaking river clean up. There was a lot more garbage than I thought and realized that my friends and I were making a difference just by being there and picking trash in the river. I go back to that clean up every year. That was my first true volunteer community service and I found it to be a positive experience and that's sparked not only a want to volunteer, but also influenced my decision to become an environmental engineer."

The results indicate that some students already had a fairly developed sense of social responsibility attitudes coming into college, and expectations for how engineering skills could help them fulfill personal service goals.

\section{College Service-Learning Courses}

The impacts of college service-learning courses on SR scores for both first-year and senior students are summarized in Table III. Among the seniors, $42 \%$ reported participating in a college service-learning course on Survey \#1. Higher service-learning course participation frequency was shown to correlate to higher average overall SR scores and higher scores related to how students see their professional obligations to help others (professional connectedness).

TABLE III.

AVERAGE SR SCORES FOR STUDENTS WITH DIFFERENTIAL PARTICIPATION IN COLLEGE SERVICE-LEARNING COURSES

\begin{tabular}{|c|c|c|c|c|c|}
\hline \multirow[b]{2}{*}{$\begin{array}{l}\text { Student Service-Learning and Community Service } \\
\text { Activities }\end{array}$} & \multirow[b]{2}{*}{$\mathrm{N}$} & \multirow[b]{2}{*}{$\begin{array}{l}\text { Average } \\
\text { SR }\end{array}$} & \multicolumn{3}{|c|}{ Average SR Realm Scores } \\
\hline & & & $\begin{array}{c}\text { Personal Social } \\
\text { Awareness }\end{array}$ & $\begin{array}{l}\text { Professional } \\
\text { Development }\end{array}$ & $\begin{array}{c}\text { Professional } \\
\text { Connectedness }\end{array}$ \\
\hline \multicolumn{6}{|l|}{ Survey \#1 (in-college service-learning) } \\
\hline Seniors & 366 & & & & \\
\hline No service-learning & 214 & $5.40^{\mathrm{T}, \mathrm{KW}}$ & 5.54 & 6.04 & $4.92^{\mathrm{T}, \mathrm{KW}}$ \\
\hline Service-learning once or twice & 116 & $5.52^{\mathrm{T}}$ & $5.60^{\mathrm{T}}$ & 6.06 & $5.15^{\mathrm{T}}$ \\
\hline SL class more than twice, monthly, or weekly & 36 & 5.71 & 5.80 & 6.05 & 5.44 \\
\hline \multicolumn{6}{|l|}{$\begin{array}{l}\text { Survey \#2 (past year service-learning) } \\
\text { Seniors without SL or EWB before senior year }\end{array}$} \\
\hline No service-learning and no EWB in senior year & 97 & $5.30^{\mathrm{T}, \mathrm{M}}$ & $5.48^{\mathrm{T}, \mathrm{M}}$ & $6.06^{\mathrm{T}}$ & $4.78^{\mathrm{T}, \mathrm{M}}$ \\
\hline Service-learning during senior year & 30 & 5.69 & 5.85 & 6.14 & 5.35 \\
\hline \multicolumn{6}{|l|}{ First-Year Students } \\
\hline No service-learning & 103 & $5.49^{\mathrm{T}}$ & 5.60 & $6.05^{\mathrm{T}}$ & 5.13 \\
\hline Service-learning once or twice & 37 & $5.52^{\mathrm{T}}$ & 5.61 & $5.87^{\mathrm{T}}$ & $5.04^{\mathrm{T}}$ \\
\hline SL class more than twice, monthly, or weekly & 21 & 5.55 & 5.75 & 6.03 & 5.36 \\
\hline
\end{tabular}

${ }^{\mathrm{T}}$ t-test statistically significant difference compared to row below, $\mathrm{p}<0.05$; $\mathrm{K}$ significance $<0.05 ;{ }^{\mathrm{M}}$ Mann-Whitney independent samples U-test significance $<0.05$ 
Forty percent of the students participated in service-learning during their senior year, based on the Survey \#2 results. In order to isolate the effects of service-learning in the senior year, students without prior service-learning or EWB participation (based on Survey \#1) were examined specifically (Table III). Only $24 \%$ of the seniors who had not participated in servicelearning or EWB prior to their senior year reported having a service-learning course in the senior year. This lower percentage compared to the seniors overall suggests that students who were interested in community service previously tended to self-select into LTS experiences as seniors. Seniors whose only college service-learning experience occurred during their senior year had higher average pre and post SR scores (5.65 and 5.69, on Survey \#1 and \#2 respectively) than students who had no service-learning experiences in college (5.22 and 5.30, on Survey \#1 and \#2 respectively).

On Survey \#2, the students were asked an open-ended question if classes over the past year had impacted their views of SR, why or in what ways. Among the seniors, $46 \%$ of 186 respondents indicated that they had taken a course that influenced their views of SR; $25 \%$ did not provide a response. The most popular courses cited were design courses $(36 \%$ of the students who cited courses), such as capstone in various disciplines, international senior design, and component design. A number of these were also service-learning projects, commonly for disabled individuals or international communities. Examples of student quotes that illustrate these ideas are:

"Senior Design class due to the project I was assigned. The project will help wounded vets retain a sense of independence through the design of a handcycle."

"Environmental Engineering Senior Design, my project focused on helping a non-profit working in a foreign country to develop renewable energy; also, the lectures hit on ethics and the social component of sustainability."

"Senior capstone design had a few international projects which made me realize that I have been taking things like health for granted. From hand crank bikes to prosthetic legs, I realize that with my ME degree I can design things to help society. "

A variety of other core courses, engineering electives, and professional issues courses were cited by $16 \%, 14 \%$, and $12 \%$ of the students who discussed courses, respectively. These courses were frequently associated with themes such as ethics, environment, and international issues. Humanities and social science courses were cited by $22 \%$ of the students; some of these were also service-learning courses.

For the first year students, small, statistically significant increases in average SR scores were evident with increasing service-learning participation in the first year of college (Table III). Looking only at students who completed all three surveys, paired t-tests across the fifty SR Likert items were used to compare an individual student response on Survey 1 and Survey 3. This analysis found that for the students who had no service-learning in college through their sophomore year, about twice as many decreased in their SR score compared to increased in their SR score (Table IV). Service-learning in college increased the percentage of the students who increased in their SR score. Over the first two years of college many more students decreased in their SR scores compared to the number who increased in their SR score, regardless of college service-learning experiences. The initial SR of the students in the cohort (Survey \#1) who did not have a college service-learning course was not significantly different than the students who did have a service-learning course in college $(\mathrm{p}=0.08)$. There was a drop in the average SR scores of the college service-learning cohort between the end of first year (Survey \#2) and the end of the 
second year (Survey \#3). This drop may have been due to a lack of service-learning or discussion of social issues during the sophomore year, which made students question the importance of social responsibility in engineering. A similar result of decreasing commitment to public welfare among engineering students was noted by $\mathrm{Cech}^{\mathrm{xxx}}$, termed a culture of disengagement.

TABLE IV. LONGITUDINAL TRENDS IN SR SCORES OVER THE FIRST TWO YEARS OF COLLEGE

\begin{tabular}{lcccccc}
\hline Student group & $\mathrm{N}$ & $\begin{array}{c}\text { \% students } \\
\text { increased SR }\end{array}$ & $\begin{array}{c}\text { \% students } \\
\text { decreased SR }\end{array}$ & $\begin{array}{c}\text { Initial } \\
\text { Average SR } \\
\text { (Survey \#1) }\end{array}$ & $\begin{array}{c}\text { End 1 } \\
\text { average SR } \\
\text { (Survey \#2) }\end{array}$ & $\begin{array}{c}\text { End soph year } \\
\text { average SR } \\
\text { (Survey \#3) }\end{array}$ \\
\hline $\begin{array}{l}\text { No college service- } \\
\text { learning }\end{array}$ & 103 & $14 \%$ & $26 \%$ & 5.45 & 5.49 & 5.47 \\
College service-learning & 42 & $22 \%$ & $27 \%$ & 5.50 & 5.53 & $5.41^{\mathrm{T}}$ \\
\hline
\end{tabular}

${ }^{\mathrm{T}} \mathrm{t}$-test significant difference compared to pre survey, $\mathrm{p}<0.05$

On Survey \#2, at the end of the first-year, 49\% (n=64) of the 130 first year students who answered the open-ended question about influential classes indicated that courses had impacted their views of SR (19\% of the students left the question blank). Of the students who listed a course, $59 \%$ cited engineering courses and $45 \%$ cited humanities and social science elective courses. Thirty percent of the discussions cited international aspects of the course, often in reference to developing countries. Introductory engineering courses were cited in $38 \%$ of the write-in responses, frequently referring to the ethics and/or environmental content in the course. Other engineering courses cited included first-year engineering projects courses $(n=9,14 \%)$ and various types of engineering elective courses $(n=6,9 \%)$. Service-learning courses were explicitly cited by seven students (10\%). Two example quotes are:

"Engineering Projects. Our professor had us work with disabled children and it... has shown me how we can help others."

"I took a first year projects class where my group made a disco ball for a person with developmental and physical disabilities. It showed me just how much engineering can improve the lives of others."

The service-learning courses cited by first-year students were unlikely to have been selfselected due to service opportunities. The first year projects course at the large public institution has multiple sections, some that are service-learning oriented and others that are not. Students do not know the type of projects in the course when they register.

\section{College Extracurricular Engineering Service Impacts Over First Two Years}

The SR attitudes of students who participated in EWB during their first two years of college were explored by looking at average SR scores from Survey \#1 and \#3 from the students who were first-year students when Survey \#1 was administered. The longitudinal results (Table V) showed that the incoming SR attitudes of the first-year students seemed to predict their engagement with EWB. The EWB engagement frequency number shown in the table was summed over the surveys at the end of the students' first and second years (Survey \#2 and \#3, respectively). For example, a score of 1 is a student who participated once in either the first or second year. A score of 4 represents a student who participated with EWB twice per year in both of their first two years of college or perhaps a student who participated monthly in their first year 
of college but not at all in sophomore year. A score of 10 represents a student who participated weekly in both years. Students with the highest average SR scores incoming to college had the greatest level of engagement with EWB and continued to have the highest SR scores. What is not clear is that EWB participation itself positively impacted the SR attitudes of these students. There were no statistically significant changes over time for the overall cohort at the highest EWB participation. At an individual level, the group with the highest EWB participation did have the highest percentage of individuals who increased in SR scores over time.

TABLE V.

LONGITUDINAL TRENDS IN SR SCORES FOR STUDENTS WITH DIFFERENT LEVELS OF ENGAGEMENT WITH EWB OVER

\begin{tabular}{|c|c|c|c|c|c|c|}
\hline $\begin{array}{l}\text { Level of } E W B \text { participation in first } \\
\text { two years of college }\end{array}$ & $\mathrm{N}$ & $\begin{array}{l}\text { Start } 1^{\mathrm{st}} \mathrm{yr} \\
\text { Average SR } \\
\text { (Survey \#1) }\end{array}$ & $\begin{array}{c}\text { End } 1^{\mathrm{st}} \mathrm{yr} \\
\text { Average SR } \\
\text { (Survey \#2) }\end{array}$ & $\begin{array}{l}\text { End } 2^{\text {nd }} y r \\
\text { Average SR } \\
\text { (Survey \#3) }\end{array}$ & $\begin{array}{c}\% \text { students } \\
\text { increased SR } \\
(\mathrm{N})\end{array}$ & $\begin{array}{c}\% \text { students } \\
\text { decreased SR } \\
(\mathrm{N})\end{array}$ \\
\hline No EWB & 132 & $5.35^{\mathrm{T}, \mathrm{KW}}$ & $5.43^{+, K W}$ & $5.36^{\mathrm{T},+, K W}$ & $17 \%(23)$ & $26 \%(34)$ \\
\hline EWB total $1-4$ & 25 & $5.69^{\mathrm{T}}$ & $5.49^{\mathrm{T},+}$ & $5.50^{\mathrm{T}}$ & $8 \%(2)$ & $36 \%(9)$ \\
\hline EWB 5 to 10 & 24 & 5.89 & 5.93 & 5.76 & $29 \%(7)$ & $25 \%(6)$ \\
\hline No EWB, no service trips & 102 & $5.32^{\mathrm{T}}$ & $5.40^{\mathrm{T}}$ & $5.32^{\mathrm{T},+}$ & $16 \%(16)$ & $24 \%(24)$ \\
\hline No EWB, service trip(s) & 30 & 5.48 & 5.54 & $5.46^{+}$ & $23 \%(7)$ & $33 \%(10)$ \\
\hline EWB 5 to 10 , no service trips & 10 & $5.81^{\mathrm{T}}$ & 5.87 & $5.58^{\mathrm{T},+}$ & $20 \%(2)$ & $40 \%(4)$ \\
\hline EWB 5 to 10 , service trip(s) & 14 & 5.96 & 5.97 & 5.91 & $36 \%(5)$ & $14 \%(2)$ \\
\hline
\end{tabular}

Students at the highest level of EWB involvement also had higher participation in on-site service trips, disaster relief, or international humanitarian volunteer activities in college (these activities may or may not have been with EWB). The group with high EWB participation and service trips had the highest initial SR and generally maintained this high level. This group had a much higher percentage of students who increased their SR over time (36\%) as opposed to decreased (14\%). In contrast, the cohort with high EWB participation but no service trips decreased significantly in SR between the end of first year and end of sophomore year, with $40 \%$ of the students decreasing in SR versus only $20 \%$ increasing. This seems to indicate a significant role of direct interaction with the community. Many schools have a high number of students participating in EWB, but relatively few students visit their international community partner (due to time, monetary commitment, and/or burden on the partner community).

Only six of the open-ended comments by students at the end of sophomore year described EWB as an event that impacted their views of SR, with one mention of a similar service organization, Bridges To Prosperity. This represents only $14 \%$ of the students who participated in EWB or a similar group. Two example quotes from students are:

"My involvement in Engineers Without Borders has increased my desire to help people with engineering."

"I am a member of the Engineers Without Borders project at my university. This has helped me realize how I can help communities in need using skills I have developed in my classes."

\section{College Extracurricular Engineering Service Impacts for Senior Students}

The average SR scores of senior students with different levels of self-reported participation in EWB are shown in Table VI. Senior students with greater EWB participation had higher 
average SR scores on Survey \#1, with the largest effects on their views of professional obligation to help others (professional connectedness). The highest SR scores were found among the small number of students who participated in EWB weekly and had also participated in one or more on-site service trips. EWB or service trip participation was also associated with higher SR among seniors who had no service-learning participation during college. It is likely that individuals with high social responsibility elect to participate in EWB, which is supported by the first-year student data. Again, it is uncertain the extent to which EWB participation itself fosters positive attitudes towards SR. At some institutions, engineering service-learning opportunities may not be available, so these extracurricular opportunities may provide a critical way for students to enact and/or develop their social responsibility.

TABLE VI.

AVERAGE SR SCORES FOR SENIOR STUDENTS BASED ON COLLEGE PARTICIPATION IN EWB OR ON-SITE SERVICE TRIPS

\begin{tabular}{lccccc}
\hline $\begin{array}{l}\text { Participation levels in EWB or service } \\
\text { trips during college (Survey \#1) }\end{array}$ & $\mathrm{N}$ & $\begin{array}{c}\text { Average } \\
\mathrm{SR}\end{array}$ & $\begin{array}{c}\text { Personal } \\
\text { Social } \\
\text { Awareness } \\
\text { Realm }\end{array}$ & $\begin{array}{c}\text { Professional } \\
\text { Development } \\
\text { Realm }\end{array}$ & $\begin{array}{c}\text { Professional } \\
\text { Connectedness } \\
\text { Realm }\end{array}$ \\
\hline $\begin{array}{l}\text { EWB Participation } \\
\quad \text { None }\end{array}$ & 309 & $5.41^{\mathrm{T}, \mathrm{KW}}$ & $5.54^{\mathrm{KW}}$ & $6.02^{\mathrm{T}, \mathrm{KW}}$ & $4.96^{\mathrm{T}, \mathrm{KW}}$ \\
$\quad 17$ & $5.64^{\mathrm{T}}$ & $5.62^{\mathrm{T}}$ & 6.18 & $5.31^{\mathrm{T}}$ \\
$\quad$ Once or twice & 40 & $5.84^{\mathrm{T}}$ & 5.88 & 6.21 & $5.60^{\mathrm{T}}$ \\
$\quad$ More than twice, monthly, or weekly & 11 & 6.08 & 6.02 & 6.29 & 5.99 \\
EWB weekly with on-site service trip(s) & & & & $6.00^{\mathrm{T}}$ & $4.83^{\mathrm{T}, \mathrm{M}}$ \\
\hline No Service-Learning in College & 163 & $5.32^{\mathrm{T}, \mathrm{M}}$ & $5.46^{\mathrm{T}, \mathrm{M}}$ & 6.15 & 5.22 \\
$\quad$ No EWB, no service trip & 51 & 5.62 & 5.78 & \\
$\quad$ EWB or service trip(s)
\end{tabular}

$\mathrm{T}$ t-test statistically significant difference compared to row below, $\mathrm{p}<0.05 ; \mathrm{M}=$ Mann-Whitney independent samples $\mathrm{U}$ test significance $<0.05 ; \mathrm{KW}=$ Kruskal-Wallis independent samples test significance 0.05

Again, looking beyond the SR averages, the student responses to the open ended questions were explored. Students were asked to "briefly describe any events that have influenced their views of community service and social responsibility"; but on Survey \#1 among the 57 seniors who participated in EWB, only seven (12\%) mentioned EWB. Example quotes from seniors are:

"Traveled to Nepal in Dec. 2011 for EWB project; saw firsthand how quality of life is in developing communities."

"Working with EWB and in the process, learning how people in other parts of the world live has caused me to feel greater responsibility towards people."

Some of the other international work that four (7\%) students wrote about may also have been affiliated with EWB. For example:

"Working in a hospital in a developing nation (Quito, Ecuador), working in a school in rural Peru."

The low percentage of EWB participants who cited EWB as an event that influenced their views may be evidence that, for many students, EWB participation was elected due to pre-existing SR attitudes, and for only a few students did EWB participation directly foster their sense of SR.

Three seniors noted some negative aspects of EWB:

"...our EWB chapter is disorganized."

"The way EWB-XU is run changed my perceptions of the way the organization and nonprofit/NGO/types are run in general. Non-profits have complex dynamics and their organization can be frustrating at times making it difficult for certain types of people." 
"Friends associated with EWB and their experiences in developing communities and how we can both help and hurt a community through drag and drop engineering."

Many of the students who participated in EWB (47\%) cited local volunteer activities (food bank, blood drive) or domestic problems (homeless, disasters) as impacting their views of SR and community service, with some specifically indicating that these were activities with their family, church, or in high school. Examples of these statements from students are:

"Did a lot of volunteering in high school with animal shelters, retirement homes, and teaching and always saw great appreciation for my efforts."

"Growing up my parents always took me to volunteer at a local food pantry place. One day I saw a girl from my 3 rd grade class there. It made me realize that the people I am involved with can be the ones struggling."

For many students the development of their social responsibility attitudes began long before college.

\section{Impacts of Individual Service Activities on Senior Students}

Seniors who had only engaged in one type of the three community service activities of interest (service-learning, EWB participation, and short term on-site service experience) on Survey \#1 were explored (Table VII), to further isolate the effects of individual types of community service. The seniors who reported only participating with EWB had the highest overall average SR, and also had the highest scores in the personal social awareness and professional connectedness realms. Within the personal social awareness realm the students who had not participated in any of these three community service activities were not significantly different than the students who participated only in service-learning during college courses, countering expectations that service-learning would positively affect the development of personal social awareness. The students who had participated in short term on-site trips or EWB, however, had stronger views of personal ability and obligation to help others (personal social awareness). This is logical since higher personal SR would encourage someone to voluntarily participate in a service trip or EWB. There were no statistically significant differences in the professional development realm associated with engagement in any of these three forms of community service. In the professional connectedness realm, only those students who did not engage in any of the three forms of community service were different (lower) than the other groups. This indicates that any community service engagement, whether voluntary or not, positively impacted professional connectedness.

TABLE VII.

THE EFFECTS OF INDIVIDUAL TYPES OF COMMUNITY SERVICE ACTIVITIES ON THE SURVEY \#1 SR SCORES OF SENIORS

\begin{tabular}{|c|c|c|c|c|c|}
\hline \multirow[b]{2}{*}{ Community Service Activity } & \multirow[b]{2}{*}{$\mathrm{N}$} & \multirow[b]{2}{*}{$\begin{array}{l}\text { Average } \\
\text { SR }^{\mathrm{KW}}\end{array}$} & \multicolumn{3}{|c|}{ Average Scores in Different SR Realms } \\
\hline & & & $\begin{array}{l}\text { Personal Social } \\
\text { Awareness }\end{array}$ & $\begin{array}{l}\text { Professional } \\
\text { Development }\end{array}$ & $\begin{array}{c}\text { Professional } \\
\text { Connectedness }\end{array}$ \\
\hline None & 156 & $5.33^{\mathrm{a}}$ & $5.46^{\mathrm{a}}$ & 6.01 & $4.84^{\mathrm{a}}$ \\
\hline Service-learning courses only & 77 & $5.40^{\mathrm{b}}$ & $5.50^{\mathrm{a}}$ & 5.99 & $4.98^{\mathrm{b}}$ \\
\hline Service trips only & 34 & $5.45^{\mathrm{b}, \mathrm{c}}$ & $5.67^{\mathrm{b}}$ & 6.00 & $4.99^{\mathrm{b}}$ \\
\hline EWB only & 14 & $5.52^{\mathrm{c}}$ & $5.71^{\mathrm{b}}$ & 6.12 & $5.05^{\mathrm{b}}$ \\
\hline
\end{tabular}

${ }^{\mathrm{KW}}$ These scores were statistically significantly different between the different community service activity groups, based on a Kruskal-Wallis independent samples test, significance $<0.005$; a,b,c Different superscripts denote statistical differences between the service activities, based on a t-test at $\mathrm{p}<0.05$ 


\section{CONCLUSIONS AND FURTHER WORK}

The research found evidence that participation in service-learning courses correlated with more positive attitudes toward engineers' social responsibility. Service-learning course experiences over the first two years of college benefited professional social responsibility attitudes and did not appear to be differentially self-selected based on SR views. Research analyzing curricula found that service-learning projects were required in some required first-year engineering courses or course sections. In contrast, senior-level courses that include service-learning seemed to be differentially self-selected by students with more positive attitudes toward social responsibility. Curriculum research found that service-learning projects were generally optional in required courses or that the service-learning courses were electives. Students described service-learning experiences in high school and both engineering and non-engineering college service-learning courses as events that impacted their views of community service and social responsibility. It is uncertain if the social responsibility impacts of service-learning are different in a core engineering course where engineering skills are applied in a project to help the community as compared to a humanities course that uses a service placement model followed by reflection that ties the service experience to the learning goals of the course. The type of structured reflection activities that students engage in during the service-learning experience might impact attitudes toward social responsibility. Some community service experiences in engineering courses do not require students to reflect on the experience, ${ }^{\text {xxvii-xxviii }}$ which may be detrimental to achieving growth in personal and/or professional social responsibility attitudes. The specific frequency and type of the reflection activities may also be important. Further research into the specific attributes of college service-learning courses that are taken by engineering students should be conducted in order to distill best practices for courses that intend to impact students' sense of social responsibility. An engineering program committed to graduating students with strong social responsibility values may want to consider embedding a service-learning experience in one or more required engineering courses, ${ }^{\mathrm{xxx}}$ as well as offering elective service-learning courses. ${ }^{\text {xix }}$

Students' participation in extracurricular engineering service activities during college was also explored. Students with high social responsibility attitudes coming into college were more likely to participate in EWB in their first two years of college. Participation in service trips to communities seemed to be an important contributor to social responsibility attitudes. The presence of EWB and similar organizations, such as Bridges To Prosperity, can serve as powerful models for the role that engineers can play in improving quality of life throughout the world. These experiences may vary greatly leading to the possibility of negative experiences. International development projects often pose significant challenges, ${ }^{\text {xxxi }}$ such that working with local communities may be a better fit for many engineering programs.

The large number of engineering students who decreased in social responsibility over the first two years of college is troubling. Service-learning experiences in the first and second year increased the percentage of students who increased their SR attitudes compared to students without service-learning experiences; more students decreased in SR scores even with servicelearning. These results mirror the culture of disengagement in engineering that was observed by Cech. ${ }^{\mathrm{xxx}}$ An emphasis on the societal obligations and benefits of engineering integrated into a variety of courses may be important to combat this trend. To further explore the development of SR attitudes in engineering students and determine potential impacts on student persistence and career plans, longitudinal student interviews are in-progress as an extension of this research. The 
combined body of work may indicate college environments and activities that foster social responsibility attitudes in engineering students.

\section{ACKNOWLEDGMENT}

This material is based upon work supported by the National Science Foundation under Grant No. 1158863. Any opinions, findings, and conclusions or recommendations expressed in this material are those of the author(s) and do not necessarily reflect the views of the National Science Foundation.

\section{REFERENCES}

${ }^{\mathrm{i}}$ National Academy of Engineering (NAE), The Engineer of 2020: Visions of Engineering in the New Century. (Washington DC: NAE, 2004).

${ }^{i i}$ ABET, Criteria for Accrediting Engineering Programs Effective for Evaluation During the 2009-2010 Accreditation Cycle (Baltimore MD: ABET Engineering Accreditation Commission, 2008).

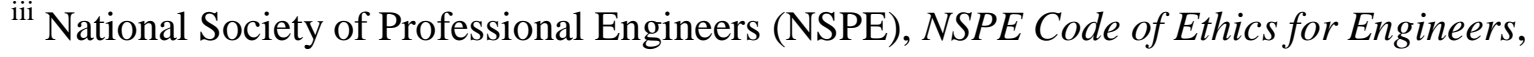
http://www.nspe.org/resources/ethics/code-ethics accessed May 13, 2014.

${ }^{\text {iv }}$ American Society of Civil Engineers (ASCE), Civil Engineering Body of Knowledge for the 21 st Century: Preparing the Civil Engineer for the Future, 2nd Edition (Reston VA: ASCE, 2008).

${ }^{v}$ American Academy of Environmental Engineers (AAEE), Environmental Engineering Body of Knowledge (Annapolis MD: AAEE, 2009).

${ }^{v i}$ American Society of Mechanical Engineers (ASME), Vision 2030: Creating the Future of Mechanical Engineering Education (New York NY: ASME, 2011).

${ }^{\text {vii }}$ Caroline Baillie, Engineering and Society: Working Towards Social Justice. Part I. Engineering and Society (San Rafael CA: Morgan \& Claypool, 2009).

viii Brock E. Barry and J.R. Herkert, "Engineering Ethics," in Cambridge Handbook of Engineering Education Research, eds. A. Johri and B.M. Olds (New York: Cambridge University Press, 2014).

${ }^{\text {ix }}$ George Catalano, Engineering and Society: Working Towards Social Justice. Part II: Engineering: Decisions in the $21^{\text {st }}$ century (San Rafael CA: Morgan \& Claypool, 2009).

${ }^{\mathrm{x}}$ J.R. Herkert, "Ways of thinking about and teaching ethical problem solving: Microethics and macroethics in engineering," Science and Engineering Ethics, 11 (2005): 373-385.

${ }^{x i}$ Donna Riley, A.E. Slaton, and A.L. Pawley, "Social Justice and Inclusion: Women and Minorities in Engineering," in Cambridge Handbook of Engineering Education Research, eds. A. Johri and B.M. Olds (New York: Cambridge University Press, 2014).

${ }^{x i i}$ Nathan Canney and A. Bielefeldt, "A framework for the development of social responsibility in engineers," International Journal of Engineering Education. In press (2014).

xiii S. Schwartz, "Normative influences on altruism," Advances in experimental social psychology, 10 (1977), 221-279.

${ }^{\text {xiv }}$ S. H. Schwartz and J. A. Howard, "Helping and Cooperation: A Self-Based Motivational Model," in Cooperation and Helping Behavior: Theories and Research (New York: Academic Press, Inc., 1982), 327-353. 
${ }^{\mathrm{xv}}$ Linda Vanasupa, L. Slivovsky and K. C. Chen, "Global challenges as inspiration: A classroom strategy to foster social responsibility," Science and Engineering Ethics, 12 (2006): 373-380.

${ }^{x v i}$ C. L. Delve, S. D. Mintz and G. M. Stewart, "Promoting values development through community service: A design," New Directions for Student Service, 4 (1990): 7-29.

${ }^{x v i i}$ Chris W. Swan, J.J. Duffy, K. Paterson, A.R. Bielefeldt, and O. Pierrakos, "The EFELTS project - Engineering Faculty Engagement in Learning Through Service," Paper AC 2011-1324, American Society for Engineering Education Annual Conference \& Exposition Proceedings (Washington DC: ASEE, 2011).

xviii Corporation for National and Community Service, Office of Research and Policy Development, Community Service and Service-Learning in America's Schools (Washington D.C.: Corporation for National \& Community Service, 2008).

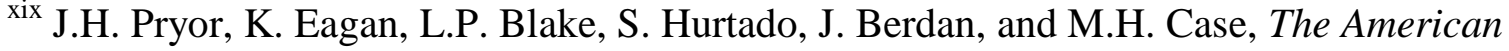
Freshman: National Norms Fall 2012. Expanded Edition (Los Angeles CA: Cooperative Institutional Research Program (CIRP) at the Higher Education Research Institute at UCLA, 2012).

${ }^{\mathrm{xx}}$ J.H. Pryor, S. Hurtado, L. DeAngelo, L.P. Blake, S. Tran, The American Freshman: National Norms Fall 2009. Expanded Edition (Los Angeles CA: Cooperative Institutional Research Program (CIRP) at the Higher Education Research Institute at UCLA, University of California Press, 2009).

${ }^{x x i}$ Community Service and College Admissions Study. 2010. www.DoSomething.org/collegesurvey

${ }^{x x i i}$ Chris Swan, K. Paterson, and A. Bielefeldt, "Community Engagement in Engineering Education as a Way to Increase Inclusiveness," in Cambridge Handbook of Engineering Education Research, eds. A. Johri and B.M. Olds (New York: Cambridge University Press, 2014).

xxiii Angela Bielefeldt and J. Pearce, "Service learning in engineering," in Convergence: Philosophies and Pedagogies for Developing the Next Generation of Humanitarian Engineers and Social Entrepreneurs, ed. T. Colledge (USA: International Journal for Service Learning in Engineering (IJSLE), 2012).

${ }^{\text {xxiii }}$ Angela R. Bielefeldt, K. Paterson, C. Swan, O. Pierrakos, D.O. Kazmer, A. Soisson. "Spectra of learning through service programs," American Society for Engineering Education Annual Conference \& Exposition Proceedings. (Washington D.C.: ASEE, 2013).

${ }^{\text {xxiv }}$ Bringle, R.G., Hatcher, J.A, "Implementing service-learning in higher education," Journal of Higher Education, 67 (1996): 221-229.

${ }^{\mathrm{xxv}}$ MaryBeth Lima and W. Oakes. Service-Learning: Engineering in Your Community, Second Edition (New York: Oxford University Press, 2013).

Rachel Parker-Gwin and J.B. Mabry, "Service learning as pedagogy and civic education: comparing outcomes for three models," Teaching Sociology, 26 (1998): 276-291.

Angela R. Bielefeldt, Mandar M. Dewoolkar, Kevin M. Caves, Bruce W. Berdanier, and Kurtis G. Paterson, "Diverse models for incorporating service projects into engineering capstone design courses,” International Journal of Engineering Education, 27 (2011): 1206-1220.

${ }^{x x x v}$ Bowa G. Tucker, D.O. Kazmer, O. Pierrakos, C. Swan, A.R. Bielefeldt, K. Paterson, A. Soisson, "Faculty perspectives on service-learning in engineering education: challenges and opportunities," American Society for Engineering Education Annual Conference \& Exposition Proceedings (Washington DC: ASEE, 2013), Paper ID \#6469. 
${ }^{\text {xxix }}$ E.J. Coyle, L.H. Jamieson, and W.C. Oakes, "EPICS: Engineering Projects in Community Service," International Journal of Engineering Education, 21 (2005): 139-150.

${ }^{\mathrm{xxx}}$ Duffy, J., L. Barrington, C. West, M. Heredia, C. Barry, "Service-Learning Integrated throughout a College of Engineering (SLICE)," Advances in Engineering Education. 2 (2011): 9-32.

${ }^{x x i}$ S.C. Seider, S.A. Rabinowicz, S.C. Gillmor, "The impact of philosophy and theology service-learning experiences upon the public service motivation of participating college students," The Journal of Higher Education, 82 (2011): 597-628.

${ }^{x x x i i}$ L.E. Whitman and C. Mason, "Assessing service learning reflections," American Society for Engineering Education Annual Conference \& Exposition Proceedings (Washington DC: ASEE, 2013), Paper ID \#7092.

xxxiii Kaitlin Litchfield and Amy Javernick-Will, "Investigating gains from EWB-USA involvement," Journal of Professional Issues in Engineering Education and Practice, 140 (2014): 04013008.

${ }^{\text {xxxiv }}$ Bernard Amadei and R. Sandekian, "Model of integrating humanitarian development into engineering education," Journal of Professional Issues in Engineering Education and Practice, 136 (2010): 84-92.

${ }^{x x x v}$ Nathan Canney, “Assessing Engineering Students' Understanding of Personal and Professional Social Responsibility" (PhD diss., University of Colorado Boulder, 2013).

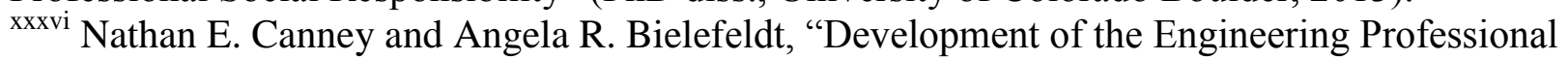
Responsibility Assessment tool to measure social responsibility in students," Journal of Engineering Education (in review 2014).

xxxvii Joost C.F. de Winder and Dimitra Dodou, "Five-Point Likert Items: t test versus MannWhitney-Wilcoxon," Practical Assessment, Research \& Evaluation, 15 (2010): 1-16.

xxxviii J.L Rasmussen, "Analysis of Likert-scale data: A reinterpretation of Gregoire and Driver," Psychological Bulletin, 105 (1989), 167-170.

xxxix Bruce L. Berg, "An introduction to content analysis," Chapter 11 in Qualitative research methods for the social sciences (6th ed. Boston, MA: Allyn and Bacon, 2007).

${ }^{\mathrm{xxx}}$ Erin A. Cech, "Culture of disengagement in engineering education?" Science, Technology, and Human Values, 39 (2014): 42-72.

xxxxi Dean Nieusma and Donna Riley, "Designs on development: engineering, globalization, and social justice,” Engineering Studies, 2 (2010): 29-59. 